\title{
MOLECULAR DIVERSITY OF SECONDARY METABOLITE-PRODUCING MARINE MICROORGANISMS ASSOCIATED WITH INDONESIAN REEF'S INVERTEBRATES
}

\author{
Ocky Karna Radjasa* and Agus Sabdono \\ Center for Tropical Coastal and Marine Studies \\ Department of Marine Sciences, Diponegoro University, Semarang, 50275, Indonesia \\ *e-mail: ocky_radjasa@yahoo.com
}

\begin{abstract}
The metabolites from microorganisms are a rapidly growing field, due to the suspicion that a number of metabolites obtained from reef's invertebrates are produced by associated microorganisms. Less than $2 \%$ of microbial flora has been successfully isolated from marine environment. Coral reefs are the most diverse marine ecosystems, however, little is known about the microbial diversity in these ecosystems. It is expected that still quite a few parts of unexplored culturable invertebrate-associated microorganisms exists in the reef environments. The present study aimed at estimating the biodiversity of secondary metabolite-producing microbes associated with reef's invertebrates such as coral, soft coral and sponge collected from geographically different areas.
\end{abstract}

Keywords: Molecular diversity, Microorganisms, Reef, Invertebrate, Secondary metabolites

\section{INTRODUCTION}

The oceans are the source of a large group of structurally unique natural products that are mainly accumulated in invertebrates that are common to coral reef ecosystems, such as sponges, tunicates, bryozoans, soft corals and molluscs. Several of these secondary metabolites showed pronounced pharmacological activities and are interesting candidates for new drugs and coral reef ecosystem has been one of the main sources for the search of bioactive compounds (Radjasa, 2003).

Serious obstacle to the ultimate development of most marine natural products that are currently undergoing evaluation and trials is the problem of supply due to their low concentrations (Munro et al., 1999). The concentrations of many highly active compounds in marine invertebrates are often minute, sometimes accounting for less than $10^{-6 \%}$ of the wet weight (Procksch et al., 2002).

In addition, it has often proven extremely difficult, and some cases impossible, to provide from invertebrates sufficient amounts of many of these substances due to limited amounts found in the producing organism, or to limited quantity of the organism itself, or to geographic, seasonal or sexual variations in the amounts and in the nature of produced secondary metabolites (Kelecom, 2002).

Regarding the use of reef's invertebrates as sources of bioactive compounds, it has been primarily concerned with protection of the environment and sustainability. The ecological ethics need to be taken into account, especially in the light of the importance of coral reefs for human population in tropical coastal communities. Thus, considering bioethical perspectives and finding alternative solutions to the problem supply for bioactive compounds mainly produced by reef's invertebrates should be given high priority.

Many marine species have been collected in the search for novel bioactive compounds and for developing pharmaceutical drugs (Hooper et al., 1998; Quinn et al., 2002). The collections tend, however, to focus on organisms containing chemicals, known as secondary metabolites that primarily serve ecological functions in competition for space and in protection from predation, fouling, 
and ultraviolet light (Harper et al., 2001), as well from bacterial infections (Correa, 1997; Rohwer et al., 2002) To date, the majority of novel compounds have been secondary metabolites from soft-bodied, sessile invertebrates, such as Porifera (sponges); Cnidaria (jellyfish, corals, sea anemones); and Urochordata (ascidians).

To date, the primary target for marine bioprospecting has been tropical seas. Coral reefs have been targeted for bioprospecting because they host a high level of biodiversity and are often characterised by intense competition for space, leading to a chemical warfare among sessile organisms.

The collections tend, however, to focus on organisms containing chemicals, known as secondary metabolites that primarily serve ecological functions in competition for space and in protection from predation, fouling, and ultraviolet light as well from bacterial infections (Pawlik et al., 2002; Becerro et al., 1997; Hellio et al., 2005). The occurrence of large scale of bioactive compounds is not common to all living organisms, but restricted to certain taxonomic groups. Among marine animals, reef's invertebrates are the most prolific producers of secondary metabolites.

Perhaps the most significant problem that has hampered the investigation of secondary metabolites is their low concentration. In marine invertebrates many highly active compounds contribute to $<10^{-6} \%$ of the body-wet weight (Proksch et al., 2002; Radjasa et al., 2007).

There has an increasing concerns regarding the collecting reef's organisms for the discovery and development of pharmaceuticals since it has been perceived variously as sustaining and threatening conservation. There is an urgent need to take into account the bioethical considerations in anticipating the potential consequences of these activities and proposing management options for sustainable use of reef's invertebrates as the sources of bioactive compounds (Sukarmi and Radjasa, 2007).

Understanding of marine invertebratemicrobial associations is a fundamental step in studying biologically potential active, possible medicinal compounds from associated bacteria. In particular, from sustainability point of view, isolating bioactive-producing bacteria or their genes involved in the biosynthesis of bioactive compounds is obviously offers a much better approach than cultivating and harvest invertebrates, which are in most cases extremely difficult.

Recently, PCR amplification of degenerate primers targeted to sequences of genes essential in the biosynthesis of particular secondary metabolites has been used to estimate the genetic ability of reef's microorganisms to produce compounds belonging to Non-ribisomal peptide syntethases (NRPS), and polyketide synthases (PKS) (Radjasa and Sabdono, 2003; Radjasa et al., 2007a, b).

The present work is aimed at screening of marine bacteria associated with reef's invertebrates for the production of secondary metabolites against indicator organisms coupled with PCR-based analysis for the presence of PKS and NRPS of the active isolates followed by subsequent DNA sequencings.

\section{MATERIALS AND METHODS}

\section{Sampling and isolation of soft coral-associated bacteria}

Colonies of coral were collected from Teluk Awur water, Jepara, North Java from a depth of five meters. Colonies of softcoral were collected from Peucang Island, West Java from a depth of three meters. Sponge colonies were obtained from Menjangan Kecil Island, Karimunjawa, Java Sea from a depth of five meters. All specimen collections were performed by scuba diving. Upon collection soft coral, coral and sponge colonies were put into sterile plastic bags (Whirl-Pak, Nasco, USA). The tissues were then rinsed with sterile seawater and scraped off with a sterile knife. The resultant tissues were serially diluted, spread on $1 / 2$ strength ZoBell $2216 \mathrm{E}$ marine agar medium and incubated at room temperature for 48 hours. On the basis of morphological features, colonies were randomly picked and purified by making streak plates (Madigan et al., 2000).

\section{Isolation of marine biofilm-forming bacteria}

Isolation was carried out with a method modified from Harder et al. (2003). Four presterilized glass slides had been deployed in four different places around soft coral colony for a week. The biofilm developed in these glass slides were then put into sterile petri dish, rinsed with sterile seawater and scrapped off with a sterile knife. The resultant mixture was diluted. One hundred $\mu 1$ of each dilution was spreaded onto $1 / 2$ 
strength ZoBell2216E and incubated at room temperature for 48 hours. Colonies with distinguished feature were selected and purified.

\section{Screening of coral bacteria with biological activity}

To screen their biological activity, bacterial isolates were tested against marine biofilm forming bacteria, and pathogenic bacteria. One $100 \mu 1$ culture of each indicator microorganism in the logarithmic phase (ca. $10^{9}$ cells $\mathrm{ml}^{-1}$ ) was spread on to agar medium. Several paper disks ( 8 mm; Advantec, Toyo Roshi, Ltd, Japan) containing $10 \mu \mathrm{l}$ of invertebrate bacterial strain were placed on the respective agar surface. The plates were then incubated at room temperature for 48 hours. Biological activity was defined by the formation of inhibition zones around the paper disk. Isolates showed biological activity against indicator organisms were chosen for further screening based on PCR technique by using specific primers of Non-ribosomal peptide synthetase (NRPS) and Polyketide synthases (PKS).

\section{PCR-based analysis of NRPS and PKS producing bacterial strains}

To obtain genomic DNA of secondary metabolite producing-strains for PCR analysis, cell materials were taken from an agar plate, suspended in sterile water (Sigma, Germany) and subjected to five cycles of freeze $\left(-80^{\circ} \mathrm{C}\right)$ and thaw $\left(95^{\circ} \mathrm{C}\right)$ (Radjasa et al., 2007c). Amplification of peptide synthetase gene fragments was carried out with the NRPS degenerated primers A2gamF ( $5^{\prime}$-AAG GCN GGC GSB GCS TAY STG CC-3') and A3gamR (5' -TTG GGB IKB CCG GTS GIN CCS GAG GTG-3') (Marahiel et al., 1997) and PKS degenerated primers KSDPQQF (5'-MGN GAR GCN NWN SMN ATG GAY CCN CAR CAN MG-3') and KSHGTGR (5'-GGR TCN CCN ARN SWN GTN CCN GTN CCR TG -3') (Piel, 2002). The NRPS-PCR run comprised 40 cycles with denaturing conditions for $1 \mathrm{~min}$ at $95^{\circ} \mathrm{C}$, annealing for $1 \mathrm{~min}$ at $70^{\circ} \mathrm{C}$ and extension for $2 \mathrm{~min}$ at $72^{\circ} \mathrm{C}$, respectively. Pseudomonas sp. DSM 50117 was used as positive control. The amplification of PKS gene fragments included an initial denaturating step at $94^{\circ} \mathrm{C}$ for $2 \mathrm{~min}$, followed by 45 cycles at $94^{\circ} \mathrm{C}$ for $1 \mathrm{~min}$, annealing at $55^{\circ} \mathrm{C}$ for $1 \mathrm{~min}$ and elongation at $72^{\circ} \mathrm{C}$ for $2 \mathrm{~min}$. Bacillus subtilis 168 was utilized for positive control.
Cloning and sequencing of (putative) peptide synthetase and polyketide domains

The amplified PCR-products were purified using the High Pure PCR Product Purification Kit (Roche Diagnostics, Mannheim, Germany) following the manufacturers protocol. The Big Dye Terminator Cycle Sequencing Ready Reaction Kit (Applied Biosystems) was used for subsequent sequencing on an ABI 310 analyzer (Perkin Elmer Applied Biosystems, Foster City, USA).

\section{Rapid grouping of sponge isolates by using Rep-PCR}

Rapid grouping among sponge active isolates was carried out by using rep-PCR. The method was performed according to Radjasa et al. (2007c, d).

PCR amplification and sequencing of $16 \mathrm{~S}$ rRNA gene fragments.

PCR amplification of partial 16S rRNA gene of active strains, purification of PCR products and subsequent sequencing analysis were performed according to the method of Thiel and Imhoff (2003). The partial 16S rDNA sequences of strains were compared for homology to the NCBI GenBank and EMBL databases using BLAST (Basic Local Alignment Search Tool).

\section{RESULTS}

Screening among marine bacteria associated with softcoral Sinularia sp. by using test organism of marine biofilm-forming bacteria (Table 1) revealed that four isolates were capable of inhibiting the growth of marine bioflim forming bacteria (Table 1).

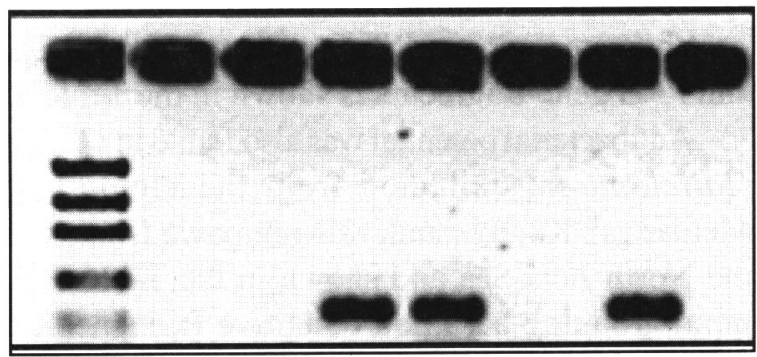

M SFNB.3 TASF $1.2+$

Figure 1. PCR amplification of NRPS gene fragments of softcoral bacteria SFNB.3 and TASF1.2. + control Pseudomonas sp. DSM 50117. 
Table 1. Characterization of marine biofilm forming bacteria.

\begin{tabular}{|c|l|l|c|l|}
\hline No & Strain & \multicolumn{1}{|c|}{ Closest relative } & $\begin{array}{c}\text { Homology } \\
(\%)\end{array}$ & \multicolumn{1}{|c|}{ Accession number } \\
\hline 1 & BIO1.1 & Pseudoalteromonas sp. & 99 & AJ391202 \\
\hline 2 & BIO1.7 & Vibrio harveyi & 97 & AJ672389 \\
\hline 3 & BIO1.8 & Staphylococcus sciuri & 97 & S83569 \\
\hline 4 & BIO2.6 & Tenacibaculum marilutum & 97 & AY661693 \\
\hline
\end{tabular}

Table 2. Inhibitory interaction of softcoral bacteria against biofilm-forming bacteria.

\begin{tabular}{|l|l|c|c|c|c|}
\hline \multirow{2}{*}{ Strain } & \multicolumn{2}{|c|}{ Closest relative } & \multicolumn{4}{c|}{ Marine biofilm-forming bacteria } \\
\cline { 3 - 6 } & & BI01.1 & BI01.7 & BI01.8 & BIO2.6 \\
\hline SFNB.3 & Arthrobacter nicotianae & - & + & - & + \\
\hline PPSF3.7 & Pelagiobacter variabilis & - & + & + & + \\
\hline TASF4.3 & Shewanella alga & + & + & - & - \\
\hline TASF1.2 & Pseudomonas fluorescens & - & - & + & - \\
\hline
\end{tabular}

Table 3. Characterization of the NRPS gene fragments of softcoral bacteria.

\begin{tabular}{|c|c|l|}
\hline \multicolumn{1}{|c|}{ Strain } & Length $(\mathrm{bp})$ & \multicolumn{1}{c|}{ Closest gene fragment } \\
\hline SFNB.3 & 416 & $\begin{array}{l}\text { Actinoplanes teichomyceticus tecR gene, ORF's 1 \& 2 (62.46\%). Acc. No. } \\
(\text { X56928) }\end{array}$ \\
\hline TASF1.2 & 389 & $\begin{array}{l}\text { putative acetylase, pvdS, putativethioesterase, and pyoverdine synthetase A } \\
(\text { pvsA) genes (77\%)Acc. AF237701 }\end{array}$ \\
\hline
\end{tabular}

PCR-based screening showed that two softcoral isolates amplified NRPS gene fragments as indicated in the Figure 1. Following cloning and sequencing of the NRPS products, the results showed that both NRPS products had homology to peptide synthetase gene fragments (Table 3 ).

Antibacterial activity was also shown by coral bacteria as indicated in the Table 5 .

One of coral bacteria was able to amplify the NRPS gene fragment (BJB) and another one, BJ.7 amplified PKS gene fragment (Fig. 2 and 3 ). Characterization of the produced both NRPS and PKS gene fragments is shown in the Table 4.

Antibacterial potential was also found in sponge Haliclona sp. collected from the vicinity of Menjangan Kecil Island, Karimunjawa Islands of the North Java Sea and shown in the Table 6. A rapid grouping based on repetitive PCR method was carried out to group the active isolates (Fig. 4). Six isolates were selected for further DNA sequencing. The identification of the representative isolates is shown in the Table 6 .

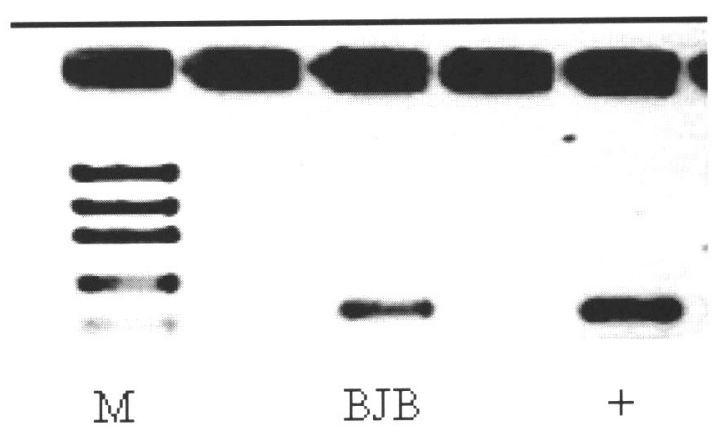

Figure 2. PCR amplification of NRPS gene fragment of coral bacterium BJB. + control Pseudomonas sp. DSM 50117.

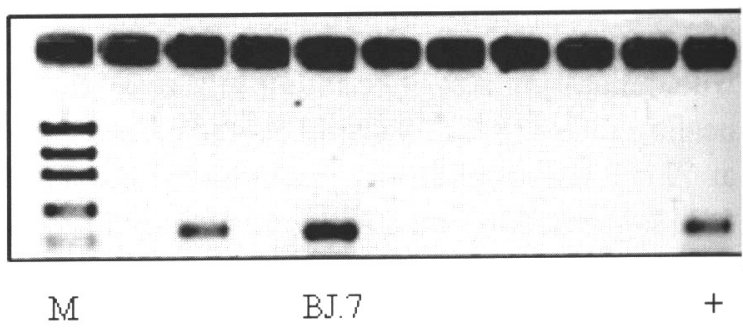

Figure 3. PCR amplitication of PKS gene tragments of coral bacterium BJ.7; + control Bacillus subtilis 168 . 
Table 4. Characterization of NRPS and PKS gene fragments.

\begin{tabular}{|l|l|l|c|l|}
\hline Strain & PKS/NRPS & \multicolumn{1}{|c|}{ Closest gene fragment } & $\begin{array}{c}\text { Homology } \\
(\%)\end{array}$ & Acc.number \\
\hline BJB & PKS & Polyketide synthase of B. subtilis & 73 & U11039 \\
\hline BJ & NRPS & $\begin{array}{l}\text { Peptide synthetase of } \\
\text { Actinoplanes teichomyceticus }\end{array}$ & 62.4 & X56928 \\
\hline
\end{tabular}

Table 5. Antibacterial activity of coral-associated bacteria.

\begin{tabular}{|l|l|l|c|c|c|}
\hline \multirow{2}{*}{ Strain } & \multicolumn{1}{|c|}{ Closest relative } & \multicolumn{2}{c|}{ Host coral } & \multicolumn{3}{c|}{ Tested bacteria } \\
\cline { 3 - 6 } & & & E.coli & B. subtilis & S. lentus \\
\hline BJ.7 & Bacillus subtilis & Acropora sp. & + & + & + \\
\hline BJB & Micrococcus sp. & Acropora sp. & - & + & + \\
\hline MJ.11 & Vibrio parahaemolyticus & Porites lutea & - & + & + \\
\hline U2SB.7 & Bacillus aquamaris & Galaxea fascicularis & - & + & + \\
\hline
\end{tabular}

Table 6. Antibacterial activity of sponge-associated bacteria against pathogenic bacteria.

\begin{tabular}{|l|l|c|c|c|}
\hline \multirow{2}{*}{ No } & \multirow{2}{*}{ Strain } & \multicolumn{3}{|c|}{ Test indicator } \\
\cline { 3 - 5 } & & V. parahaemolyticus & A. hydrophila & S. aureus \\
\hline 1 & BSP11.7 & + & + & + \\
\hline 2 & BSP11.9 & + & + & + \\
\hline 3 & BSP12.2 & + & + & + \\
\hline 4 & BSP12.3 & + & + & + \\
\hline 5 & BSP5.7 & + & + & + \\
\hline 6 & BSP11.3/A & + & + & - \\
\hline 7 & BSP10.6 & + & + & - \\
\hline 8 & BSP12.3/A & + & + & - \\
\hline 9 & BSP11.3 & + & + & - \\
\hline 10 & BSP12.1 & + & + & - \\
\hline 11 & BSP3.4/A & - & + & + \\
\hline 12 & BSP1.12 & BSP1.3A & + & + \\
\hline 13 & + & + & + \\
\hline
\end{tabular}

Table 7. Identification of bacterial isolates associated with sponges.

\begin{tabular}{|l|l|l|c|l|}
\hline No & \multicolumn{1}{|c|}{ Strain } & \multicolumn{1}{|c|}{ Closest relative } & $\begin{array}{c}\text { Homology } \\
(\%)\end{array}$ & \multicolumn{1}{|c|}{ Acc. Number } \\
\hline 1 & BSP11.7 & Alpha proteobacterium Z143-1 & 99 & AY762960 \\
\hline 2 & BSP12.3A & Brachybacterium rhamnosum & 98 & AJ414376 \\
\hline 3 & BSP5.7 & Uncultured bacterium clone TCc-18 & 98 & DQ791467 \\
\hline 4 & BSP12.1 & Pseudoalteromonas sp. JL-96 & 98 & AY745871 \\
\hline 5 & BSP1.12 & Vibrio parahaemolyticus & 99 & AF388390 \\
\hline 6 & BSP11.3 & Uncultured alpha bacterium & 99 & AJ810662 \\
\hline
\end{tabular}




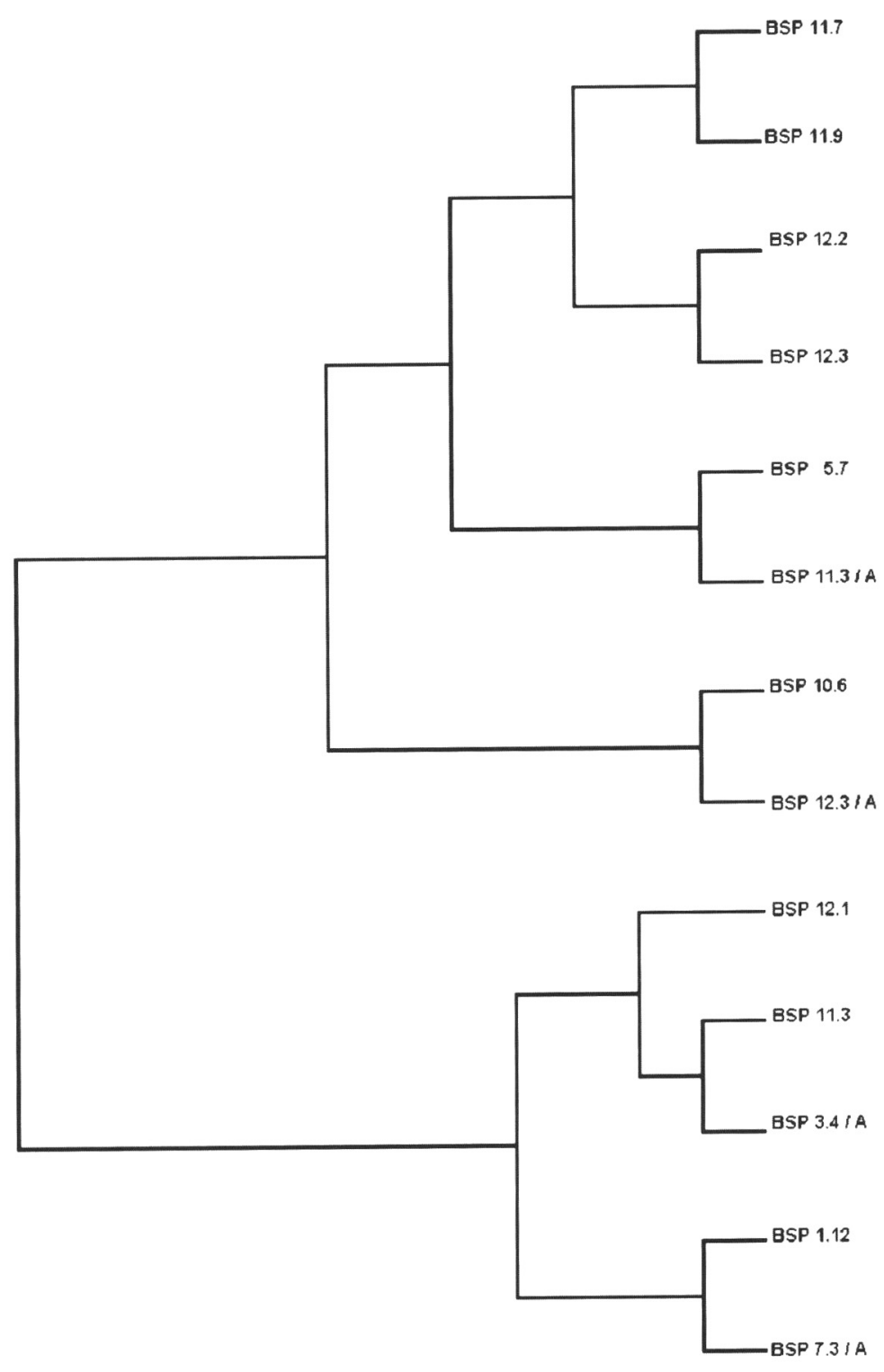

Figure 4. Dendrogram constructed based on rep-PCR of sponge isolates.

\section{DISCUSSION}

One of the most interesting aspects of the soft corals is that fouling organisms usually do not colonize their surfaces and it is believed that antifouling represents another ecological role of secondary metabolite in the alcyonacean (Sammarco and Coll, 1992). The present study showed the potential of softcoral-associated bacteria as an alternative antifoulant, in which four isolates were able to inhibit the growth of marine biofilm-forming bacteria isolated from the surrounding colonies of softcoral Sinularia sp. Furthermore, two isolates were capable of amplifying the NRPS gene fragments which after cloning and sequencing showed the homology to the peptide synthetases.

Inhibitory interactions among coral-associated bacteria that occur on the coral surface are of great interest to search for secondary metabolite-producing bacteria. Isolation and screening for secondary metabolite-producing bacteria in coral reef ecosystems have been strongly neglected until now. Our results highlight four coral-associated bacteria inhibited the growth of tested bacteria (Table 5). Furthermore, one isolate carrying the NRPS and another one carrying the PKS gene fragments. 
Sponges (phylum Porifera) are most primitive of the multicelled animals that have existed for 700-800 million years. Of the approximately 15,000 sponge species, most occur in marine environments. Only about $1 \%$ of the species inhabits freshwater (Belarbi et al., 2003).

It has been known that sponges produce secondary metabolites to repel and deter predators (Becerro et al., 1997), and for communication and protection against infection. In addition, potentially therapeutic compounds identified in sponges include anticancer agents and immunomodulators. Some sponges seem to produce potentially useful antifouling agents (Hellio et al., 2005).

From the present study, it is interesting to note that collected sponge Haliclona sp. offered potensial sources of secondary metaboliteproducing bacteria as indicated by the results of actibacterial tests against indicator microorganisms Aeromonas hydrophila, Staphylococcus aureus and Vibrio parahaemolyticus.

The application of molecular approach through PCR using specific NRPS and PKS primers provides detection of microorganisms with high pharmaceutical potential and is suitable to greatly improve the screening efficiency for secondary metabolite-producer among reef's invertebrateassociated bacteria.

Acknowledgements. These works were jointly funded by Indonesian International Joint Research Grant Program (RUTI III) for marine research, Indonesia-Italy Scientific and Technological Cooperation (STC), Alexander von Humboldt Foundation, Germany and Lindbergh Foundation, USA.

\section{REFERENCES}

Becerro, M.A, X. Turon, and M.J. Uriz. 1997. Multiple functions for secondary metabolites in encrusting marine invertebrates. J. Chem. Ecol., 23: 1527-47.

Belarbi, E.H., A.C Gomez., Y. Christi., F.G. Chamaco, and E.M. Grima. 2003. Producing drugs from marine sponges. Biotechnol. Adv., 21: 585-598.

Correa, J.A. 1997. Infectious diseases of marine algae: Current knowledge and approaches. Prog. Phycol. Res., 12: 149-180.

Hellio, C., M. Tsoukatou, J-P. Mare' chal, N. Aldred, C. Beaupoil, A. S. Clare, C. Vagias, and V. Roussis. 2005. Inhibitory Effects of Mediterranean Sponge Extracts and Metabolites on Larval Settlement of the Barnacle Balamus amphitrite. Mar. Biotechnol., $7: 297-305$

Hooper, J.N.A., R.J. Quinn, and P.T. Murphy. 1998. Australian biodiversity via its plants and marine organisms. A high throughput screening approach to drug discovery. In: M. Van Keulen, and M.A. Borowizka (Eds.). Biodiversity, Biotechnology \& Biobusiness. 2nd Asia-Pacific Conference on Biotechnology. Van Keulen, M. and Borowizka, M.A. (eds.) . Murdoch University, Perth, p.519-526

Kelecom, A. 2002. Secondary metabolites from marine microorganisms. An Acad. Bras. Cienc., 74: $51-$ 170

Marahiel. M.A., T. Stachelhaus, and H.D. Mootz. 1997. Modular peptide synthetases involved in nonribosomal peptide synthesis. Chem. Rev., 97: $2651-2673$

Munro, M.H.G., J.W. Blunt, E.J. Dumdei, S.J.H. Hickford, R.E. Lill, S. Li, C.N. Battershill, and A.R. Duckworth. 1999. The discovery and development of marine compounds with pharmaceutical potential. $J$. Biotechnol., 70: 15-25.

Pawlik, J.R., G. McFall, and S. Zea. 2002. Does the odor from sponges of the genus Ircinia protect them from fish predators? J. Chem. Ecol., 28: 1103-15.

Piel, J. 2002. A polyketide synthase-peptide synthetase gene cluster from an uncultured bacterial symbiont of Paederus beetles. PNAS 29: 14002-14007.

Proksch, P., R.A. Edrada, and R. Ebel. 2002. Drugs from the seas-current status and microbiological implications. Appl. Microbiol. Biotechnol., 59: 125-134.

Quinn, R.J., P. de Almeida Leone, G. Guymer, and J.N.A Hooper. 2002. Australian biodiversity via its plants and marine organisms. A high throughput screening approach to drug discovery. Pure Appl. Chem., 74:519-526.

Radjasa, O.K., T. Martens., H-P. Grossart, T. Brinkoff, A. Sabdono, and M. Simon. 2007a. Antagonistic activity of a marine bacterium Pseudoalteromonas luteoviolacea TAB4.2 associated with coral Acropora sp. J. Biol. Sci., 7(2): 239-246.

Radjasa, O.K., S.I.O. Salasia, A. Sabdono, J. Wiese, J.F. Imhoff, C. Lämmler, and M.J. Risk. 2007b. Antibacterial activity of marine bacterium Pseudomonas sp. associated with soft coral Sinularia polydactyla against Streptococcus equi subsp. zooepidemicus. Int. J. Pharmacol., 3(2): 170-174.

Radjasa, O.K., D. Nasima, A. Sabdono, K. KitaTsukamoto and K. Ohwada. 2007c. Characterization of psychrotrophic bacteria from sea waters of Makasar Strait, Indonesia. J. Biol. Sci., 7(4): 658662. 
Radjasa, O.K., A. Sabdono, Junaidi and E. Zocchi. 2007 d. Richness of secondary metaboliteproducing marine bacteria associated with sponge Haliclona sp. Int. J. Pharmacol., 3(3): 275-279.

Radjasa, O.K. 2003. Marine invertebrate-associated bacteria in coral reef ecosystems as a new source of bioactive compounds. J. Coast. Dev., 7: 65-70.

Radjasa, O.K., and A. Sabdono. 2003. Screening of secondary metabolite-producing bacteria associated with corals using 16S rDNA-based approach. $J$. Coast. Dev., 7: 11-19.
Rohwer, F., V. Seguritan, F. Azam, and N. Knowlton. 2002. Diversity and distribution of coral-associated bacteria. Mar. Ecol. Prog. Ser., 243: 1-10.

Sammarco, P.W., and J.C. Coll. 1992. Chemical adaptation in the Octocorallia: Evolutionary considerations. Mar. Ecol. Prog. Ser., 88: 93-104.

Sukarmi and O.K. Radjasa. 2007. Bioethical consideration in the search for bioactive compounds from reef's invertebrates. J. Appl. Sci., 7(8): 1235-1238.

Thiel, V., and J.F. Imhoff. 2003. Phylogenetic identification of bacteria with antimicrobial activities isolated from Mediterranean sponges. Biomol. Eng. 20: 421-423. 